\title{
Literature Review: Quality of Work Life in the 5.0 Era
}

\author{
Irine Noviani Angelia, Triana Noor Edwina Ds*', Reny Yuniasanti \\ Faculty of Psychology, Universitas Mercu Buana, Jl. Wates, Yogyakarta, Indonesia \\ *Corresponding author: edwina@mercubuana-yogya.ac.id
}

Article history: Received: 11 January 2020 Received in revised form: 28 June 2020 Accepted: 10 May 2021 Published online: 09 August 2021

\begin{abstract}
Quality of Work Life is important for companies to employ quality workers and for workers it can be useful to ensure their welfare, have a good working climate and conditions and ultimately have a personal psychological impact on each worker. Therefore, in the 5.0 era, which requires that we be able to use modern-based science (AI, robots, IoT) to serve human needs in order to create a society that enjoys life and feels comfortable. The purpose of this research is to present comparisons so that readers can enrich their understanding of quality. working life. The conclusion that influences the quality of work life in 15 (fifteen) journals that have been reviewed dominantly is seen in 9 (nine) factors from Cascio's opinion and 12 (twelve) factors from Chandranshu Sinha's opinion. In the era of society 5.0, a differentiation strategy is also needed, namely an organizational strategy that aims to produce a product or service that is different from the products or services of other companies. Human resources with good quality of work life will easily implement a differentiation strategy because the factors that influence it coupled with the use of advanced technology that are developing will advance the industry in a country.
\end{abstract}

Keywords: Quality of Work Life; Era 5.0; Human Resources, Cascio, Chandranshu Sinha.

C2021 Penerbit UTM Press. All rights reserved

\subsection{INTRODUCTION}

Human resources are important in building a country. Indonesia is still lagging behind other countries in human resource development. According to the Human Capital Index (HCI) not only compared to developed countries, Indonesia is even far behind ASEAN countries such as Vietnam. Indonesia's human capital index is 0.53 or ranked 87 out of 157 countries (Katadata.co.id, 2019). Benchmarks of the quality of work life are the level of satisfaction, motivation, involvement and commitment experienced at work (Srivastava \& Kanpur, 2014). Quality of Work Life is important for companies to employ quality workers and for workers it can be useful to ensure their welfare, have a good working climate and conditions and ultimately have a personal psychological impact on each worker. The quality of work life consists of opportunities to be actively involved in group work arrangements or mutually beneficial problem solving for employees and leaders (Wilcock \& Wright in Muindi \& K'Obonyo, 2015). The benefit of research is to provide comparisons so that readers can enrich their understanding of the quality of work life.

\subsection{LITERATURE REVIEW}

Cascio (2016), explains the perspective on the quality of work life through the perception of employees that they have a reasonable worklife suit and they are able to grow and develop as humans. This method connects QWL with the degree to which human needs are fully met". The European Foundation for the Improvement of Living and Working Conditions (in Pratiwi \& Himam, 2014) produced a survey showing that efforts to achieve a better working life and welfare for employees are an increasingly urgent issue to pay attention to. Syahnaz (in Haanurat \& Ifadhila, 2021). We can use modern-based science (AI, robots, IoT) to serve human needs to create a society that enjoys life and feels comfortable. Society 5.0 is an era where all technology is part of humanity itself. The internet is not just for sharing information but for living life. Wherever, whenever, anyone can enjoy the development of this industrial world. In the human-centered 5.0 era, a balance between economic progress and technology through a system that integrates cyberspace and physical space. The main characteristics of the era of society 5.0 include the use of advanced technology, robots, computers, computer intelligence, artificial intelligence and big data as well as human centered where human activities take advantage of technological sophistication for daily needs such as studying, working from anywhere and anytime. This is reinforced by the results of research by Potocan, Mulej, \& Nedelko (2021) which found that Corporate Social Responsibility (CSR) a regionally grounded solving of individuals' social problems and changing of CSR's environmental, social and economic dimensions according to circumstances of Society 5.0.

According to Onday (2019), the goal of society 5.0 is to make society more prosperous economically and the ultimate goal is to improve the quality of life of the community itself. In society 5.0 it also has an impact on the industry and also makes a complex social order.Quality 
of Work Life is an important subject in this article because it shows balance, both in work and in personal life, so as to increase organizational productivity and employee satisfaction. Employee satisfaction is an asset for the company because then employees will provide optimal productivity. This can be done with QWL, which is a concept directly related to satisfaction. In addition, QWL not only increases the productivity of the company but also represents employee identification and a sense of ownership and pride in their work (Casio, 2016).

\subsection{METHODOLOGY}

\section{Literature Search}

There are five steps that must be taken by researchers, namely Conducting Topic Exploration, Literature Search and Screening, Article Assessment and Selection, Literature Analysis and Synthesis and Writing Literature review: Writing Structure (Virginia \& Martin, 2018). The first stage is to explore the topic, namely to investigate the field of research that will be carried out by reviewing the literature and ensuring its relevance and relevance. The second stage is to search and screen the literature. Literature study is carried out by reviewing articles in the form of national and international scientific journals, papers and books discussing Quality of Work Life from various journals published by Elsevier, Springer, Social Indicators Research, Asian Journal of Management Research, International Journal of Caring Sciences. etc. The review starts from 2001 to 2018 which makes it easier for researchers to find out what affects the Quality of Work Life in the era of society. The third stage is to measure and select articles. The process at the selection and selection stages of this article usually requires a "trade-off" between the quality of the quantity, because researchers are more focused on quality, it will reduce the number of articles to be included in the analysis.

The fourth stage is to consider how to carry out an appropriate analysis of the selected articles. In other words, a standardized method of abstraction should be used accordingly from each article. The abstracted data can be in the form of descriptive information, such as author, year published, topic, or type of research, as well as in the form of effects and findings. The last stage is a literature review. The main objective is to produce a draft literature review article that is coherent, logistical and structured which can improve the quality of the message conveyed to the audience and can increase the likelihood of its future impact. Review articles are determined by organizing thoughts and perspectives of researchers and researchers who are effective in relation to the literature being studied and can present them in a wellarticulated text (Virginia \& Martin, 2018). The method used in writing about Quality of Work Life uses the literature study described in Figure 1.

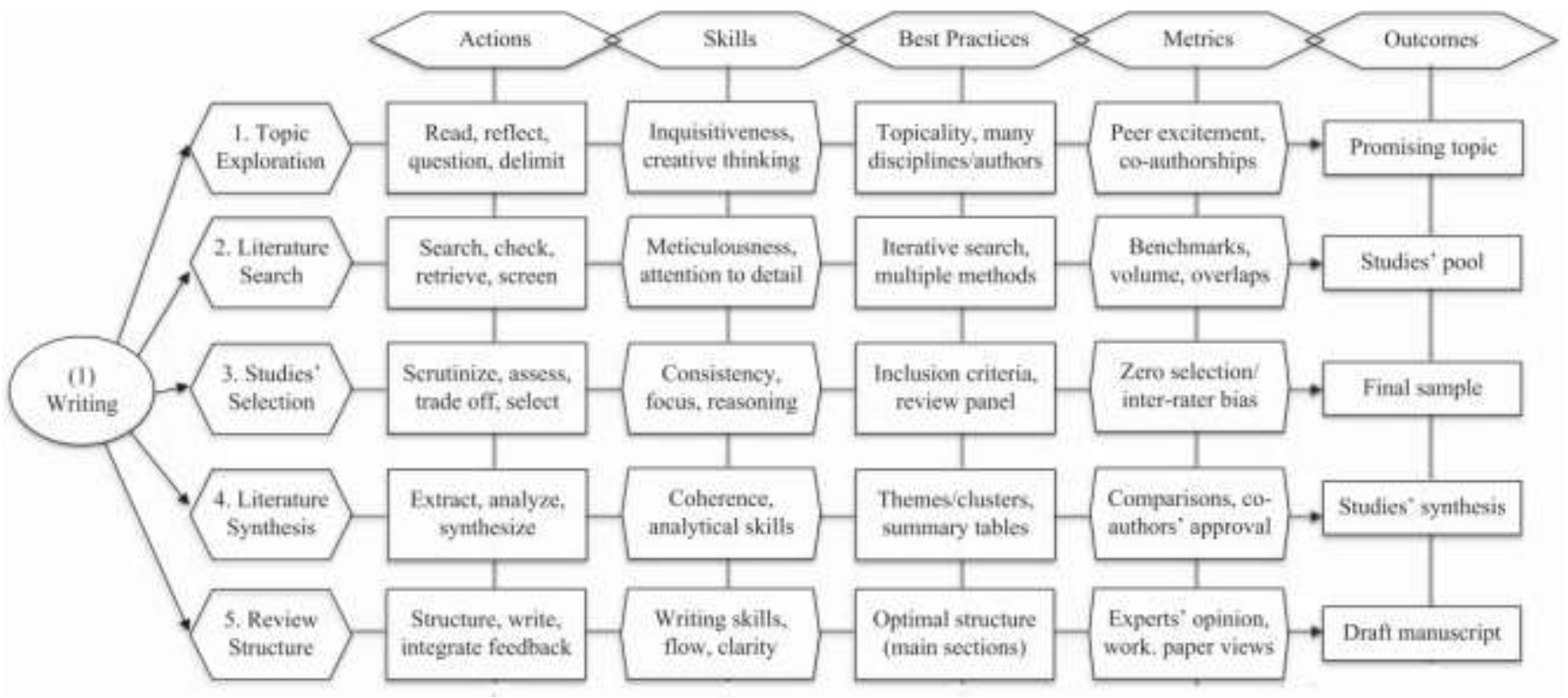

Figure 1 The stages of making a literature review

\subsection{RESULTS}

Based on the results of a review in 15 (fifteen) study published in the year 2001 to 2018 found that factors affecting the Quality of Work Life as follows: 
Table 1 Research result quality of work life

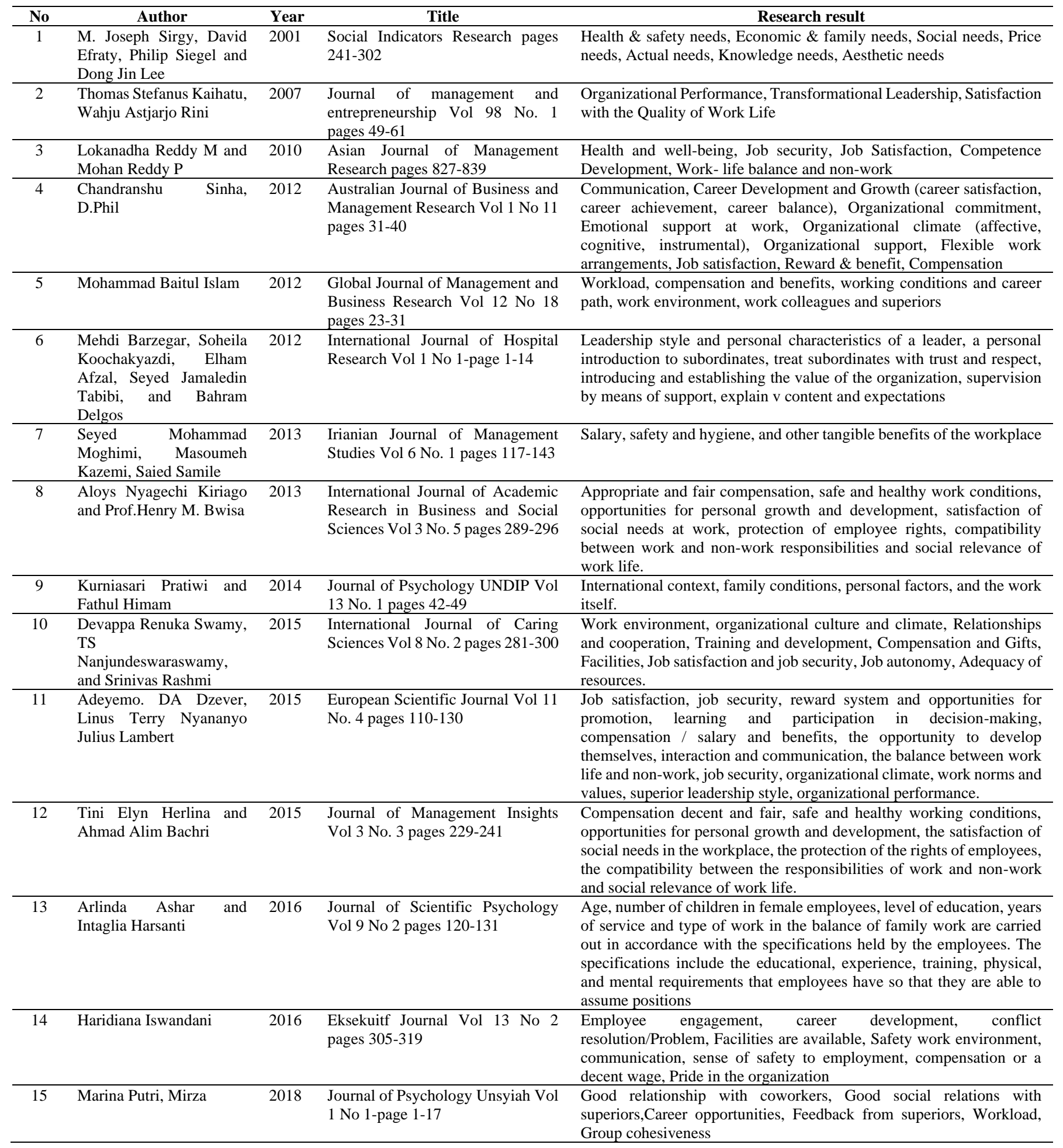

\subsection{DISCUSSION AND RECOMMENDATION}

Findings from the literature review described in table 1 of the quality of work life that distinguishes in this era of society is the era of society 5.0 where a human-centered society that balances economic and technological progress by solving problems through systems that integrate cyberspace and physical space. The main characteristics of the era of society 5.0 include technology-based namely the use of advanced technology, robots, computer, computer intelligence, artificial intelligence and big data as well as human centered where human activities that utilize technological sophistication for daily needs such as learning, working from anywhere and anytime. Literature used from 2001 to 2018 shows several factors that affect the quality of work life, namely Communication, Career Development and Growth (career satisfaction, 
career achievement, career balance), Organizational commitment, Emotional support at work, Organizational climate (affective, cognitive, instrumental), Organizational support, Flexible work arrangements, Job satisfaction, Reward \& benefit, Compensation. According to Kaswan (2017) organizations that provide good quality of work life will have a positive impact on employee work attitudes. Employees will have a high level of job satisfaction, organizational commitment, work involvement, work morale, high organizational citizenship behavior. In addition, employees will also have a good perception of fairness and organizational support. If the organization provides a good quality of work life, the syndrome of stress at work can be reduced, or further eliminated. In the era of society 5.0 differentiation strategy is also needed, namely an organizational strategy that aims to produce a product or service that is different from the products or services of other companies. Human resources with good quality of work life will easily implement differentiation strategies because the factors that influence coupled with the use of advanced technology that will develop will advance the industry in a country. Just how the use and distribution of technology and internet networks are met by the Government as the main responsible person for the progress of a country.

\subsection{CONCLUSION}

Based on the explanation above, it can be concluded that the factors that influence Quality of Work Life in 15 (fifteen) journals that have been reviewed are dominantly seen in 9 factors from the Cascio opinion and 12 factors from the Chandranshu Sinha opinion. In the era of society 5.0 differentiation strategy is also needed, namely an organizational strategy that aims to produce a product or service that is different from the products or services of other companies. Human resources with good quality of work life will easily implement differentiation strategies because the factors that influence coupled with the use of sophisticated technology that is developing will advance the industry in a country.

\section{References}

Ashar, A., \& Harsanti I. (2016). Relationship between Work Family Conflict and Quality of Work Life in Female Private Company Employees. Journal of Scientific Psychology, 9(2), 120-131.

Cascio. (2016). Managing Human Resources: Productivity, Quality of Work Life, Profits (10th ed.). Boston: McGraw-Hill.

Chandranshu Sinha. (2012). Quality Affecting Factors of Work Life: Empirical Evidence from Indian Organizations Chandranshu. Australian Journal of Business and Management Research, 7(11), 1-25.

Dzever A.D.A., Nyananyo L.T., \& Lambert J. (2015). Organizational Climate, Leadership Style and Emotional Intelligence as Predictors of Quality of Work Life Among Bank Workers in Ibadan, Nigeria. European Scientific Journal, 11(4), 110-130

Haanurat, A..I, \& Ifadhila. (2021). Utilizing Equity Crowdfunding Toward The 5.0 Society On Islamic Economic Perspective. In D. Karmiyati (Ed.), Society 5.0: Leading

In The Borderless World, 1-8. Yogyakarta: Bildung

Herlina, T. E., \& Bachri, A. A. (2015). The Effect of Demographic Characteristics and Organizational Climate on Quality of Work Life (Qwl) Banjarmasin Health Polytechnic Lecturer. Journal of Management Insights, 3(3), 229-241.

Iswandani, H. (2016). Motivation and Workload Influence on the Quality of Work Life (Quality of Worklife) and Its Impact on Employee Performance in Operations Unit Bni Pt (Persero), Tbk. Executive Journal, 13(2), 303-319.

Kaihatu, TS \& Rini, W, A. (2007). Transformational Leadership and Its Effect on Satisfaction with Quality of Work Life, Organizational Commitment, and Extra Role Behavior: Study of High School Teachers in Surabaya City. Journal of Management and Entrepreneurship, 98(1), 49-61.

Kaswan. (2017). Industrial and Organizational Psychology. Bandung: Alfabeta.

Kiriago, A. N., \& Bwisa, H. M. (2013). Working Environment Factors that Affect Quality of Work Life among Attendants in Petrol Stations in Kitale Town in Kenya. International Journal of Academic Research in Business and Social Sciences, 3(5), 289-296.

Marina, P., \& Mirza. (2018). Group Cohesiveness and Quality of Work Life in Employees. Journal of Unsyiah Psychology, 1(1), 1-17.

Moghimi, S. M., Kazemi, M., \& Samile, S. (2013). Studying the Relationship between Organizational Justice and Employees' Quality of Work Life in Public Organizations: A Case Study of Qom Province. Irianian Journal of Management Studies, 6(1), 117-143.

Onday, O. (2019). Japan's Society 5.0: Going Beyond Industry 4.0. Bus Eco J, 10, 389. https://doi.org/10.4172/2151-6219.1000389

Pratiwi, K., \& Himam, F. (2014). Quality of Work Life in Terms of Job Satisfaction and Perception of Performance. Journal of Psychology, 13(1), 42-49. https://doi.org/10.14710/jpu.13.1.42-49

Potocan, V., Mulej, M., \& Nedelko, Z. (2021). Society 5.0: Balancing of industry 4.0, economic advancement and social problems. Emerald Publishing Limited, 3(50), 794-811. DOI: $10.1108 / \mathrm{K}-12-2019-0858$

Reddy, L. M., \& Reddy, M. P. (2010). Quality of Work Life of Employees: Emerging Dimensions. Asian Journal of Management Research, 1(1), 827-839.

Sirgy, MJ, Efraty, D., Siegel, P., \& Lee, DJ (2001). A New Measure of Quality of Work Life (QWL) Based on Need Satisfaction And Spillover Theories. Social Indicators Research, 55(3), 241-302. https://doi.org/10.1023/A:1010986923468

Swamy, DR, \& Rashmi, S. (2015). Quality of Work Life: Scale Development and Validation. International Journal of Caring Sciences, 8 (2), 281-300. Retrieved from www.internationaljournalofcaringsciences.org Retrieved date: 06 January 2020.

Virginia, B., \& Martin, S. (2018). An End-To-End Process of Writing And Publishing Influential Literature Review Articles: Do's And Don'ts. Management Decision, 56(4), 1417-1450 https://doi.org/10.1108/MD-03-2018-0253 